\title{
The Study on the Status and the Countermeasures of Low-Carbon Financial System of China
}

\author{
Yuechun Wen, Yingzi Wu
}

School of Economics and Management, Tongji University, Shanghai, China.

Email: wuyz1978@yahoo.com.cn

Received October $20^{\text {th }}$, 2010; revised November $10^{\text {th }}$, 2010; accepted November $30^{\text {th }}, 2010$.

\begin{abstract}
Low-carbon economy has become the inevitable choice for the future development of human society, and can not develop without the strong support from financing system. Based on foreign low-carbon finance development experience, through studying on the status and the existing problem of the development of the domestic low-carbon finance, it is found that it is very important to improve and perfect a low-carbon financial system for China, including the low-carbon financial institutions and products system, the low-carbon financial market system, the low-carbon financial environment system and the supporting policies and measures system.
\end{abstract}

Keywords: Low-Carbon Economy, Finance System, Financial Environment System

\section{Introduction}

Global warming has become a long-term problem since the industrial revolution, which has been exacerbated by a large number of carbon emission with the modern production methods and ways of life in recent decades. It is an inevitable choice for the mankind to develop Low carbon economy and promote sustainable development of human society in the future.

However, it will require substantial capital investment to solve the problem of global warming through the development of low-carbon economy. According to Nicholas Stone's calculation, who is the former chief economist of World Bank, it need to invest 1\% of global GDP annually to stabilize atmospheric carbon dioxide at the level of $500 \mathrm{ppm}$ to $550 \mathrm{ppm}$ to meet the warming goals of less than 2 degrees, which is a huge financial burden. The major developed countries have announced the funds plan with more than 500 billion U.S. dollars for the low-carbon economy development, but there is still a financing gap about 1700 3,000 U.S billion for the annual global emission reduction. The Center for Environmental Finance think that it will lead to the abilities of the most country more and more vulnerable to solve environmental issues because of the huge cost and the big financing gap for solving environmental problems. Therefore, it is need to develop long-term environmental financing strategies for environment issues with full use of financial instruments.
It is still in its initial stage for low-carbon economy development in China. It is conspicuous that the mode of economic development is a comparatively extensive, with low efficient resource consumption and high environmental pollution. So it requires a systemic low-carbon economy policy, especially a financing system to support the economy transition from the "high carbon" to "low carbon" and then achieve the level of sustainable development.

\section{Literature Review}

\subsection{The Relation between Finance and Economy}

It is always a focus point on the relationship between financial development and economic growth in theory. There is a strong correlation between them, Beneivenga et al. [1] , King et al. [2] found that the healthy development of the financial system can promote the economy growth without other impeded economic factors, and Krugman [3] found that the imperfect financial system will hinder economic development. None economic leap is separated from the development of financial innovation in history, such as the rapid development of the First Industrial Revolution supported by the joint-stock company reform, the strong support from venture capital for the Third Industrial Revolution, and so on. Based on the "functional view", the financial system and its features were summarized by Merton [4]. It is found that the different function of the financial system will affect the de- 
cision-making of savings and investment, sound financial system can promote economic growth, while imperfections will hinder it [5], Romer [6] and Robert [7], the financial system will impact the technological innovation [8], thus affect economic growth. The financial system should have the capacity of adaptability and innovation. In the development of low carbon economy, it should play an important role, including the fund provision, establishment of an effective carbon emission trading market and the formation of accurate price signals, and the promotion of various financial derivatives emission reduction. Based on the theoretical economic growth model which make the environmental capital conversion from the exogenous factors into the endogenous, Tang, Li [9] has found that the key for the innovation of the market mechanisms should be the financial innovation which is based on the negative externalities and the environmental capital, that is, the government should define the initial property rights for environmental resources and build the energy trading market, develop environmental or carbon finance in the clean development mechanism, and guide enterprises to exchange the environment resources. As an important driving force, the financial system should adjust itself to meet the development of low-carbon economy $[10,11]$.

\subsection{Bank-Based Financing}

Some scholars have carried out some exploration on the financial support for low-carbon development, Ganzi et al. [12] survey shows that many banks have set up the environmental sector and developed friendly environmental products. On the basis of the empirical analysis, Luisa Montes et al. [13] found that the "green bank" should be different from the traditional banks, which should focus on the sustainable development sectors and projects with the active participation in the construction and supervisize the projects loan and provide various forms of financial support. Andrea B. Coulson et al. [14] have found that the environmental risks will result in the loss of credit business, so environmental risk management should be introduced to credit management procedures. Even it is difficult to determine the return on the sustainable development sectors and projects, banking sectors should set up a special green credit product, collateral and social responsibility fund for sustainable enterprises [15]. Currently, many U.S. commercial banks demonstrate the ratio of green credit, and requires the enterprises have more energy efficiency and carbon emission reduction measures when they apply for green loans. Sonia Labatt, etc. [16] extend the scope of the environmental finance products which should be led by financial institutions and transfer the environmental risk based on market, including green banking products, mortgages, weather derivatives, green funds, catastrophe bonds, and the greenhouse gas emission reduction credits. Dahlstrom et al. [17] have found that the insurance companies should play a key role in the innovation of new technology. The insurance companies have a responsibility to help develop the relevant climate policy [18-20].

Through the study of the financial operations in commercial banks, Wei Heng [21], He De-xu [22] have found the concept of environmental protection and the environmental financial risk management system should be taken into the daily management of the bank. Based on an actively exploring on the path of financial support the development of recycling economy in China, Ding Ling-hua [23] found that the policy Bank can help the formation of carbon financial market system. Based on the practical experience of carbon finance operations of Industrial Bank and analysis on the hidden risks of the development carbon financial market in China, Chen Yu [24] support that the commercial banks should speed up environmental financial innovations, take active in Carbon emissions trading and promote the construction of intermediary organizations for carbon emissions trade.

\subsection{Market-Based Financing}

According to Coase property rights theory, if the market transaction cost is zero, no matter how the initial allocation of emission rights, market transactions can make the allocation of resources achieve optimal level. But without a perfectly competitive market, the initial allocation of emission rights will affect the market transaction efficiency. Most current theories of the initial allocation of emission rights are followed mainly three types: government free distribution, public auction and the combination of both. Borenstein [25] found that it will take some time for the transition from the partial auction to the complete through the study of the validity of the initial allocation under different mechanisms. Cramton [26], etc. compared the public auction and free distribution, found that both of them have their own application conditions. Starzetakis [27] found that the initial allocation of emission rights by government is superior to market allocation scheme when it is imperfectly competitive. Li [28] discussed the complexity and guiding ideology of the initial price of emission rights at the theoretical level. Chen [29] found that the management can improve the efficiency of resource allocation through an effective initial allocation. Stavins [30] found that the transaction costs will affect the efficiency of emissions trading system and lead the total cost of pollution control rise. In the Los Angeles emissions trading market, Gandgadharan [31] found that the initial transaction costs have an important role for emissions trading, which has well explained the cause of emissions market trading is not ac- 
tive in the early stages.

Based on the current development and its unfolded financial Feature of the global carbon market, Ren [32] argues that it should accelerate the development of carbon trading market, the price discovery mechanisms, and the corresponding environmental derivative financial instruments in China. Wang [33] proposed 8 models of carbon financial innovation to solving financing problem in CDM projects. Wang et al. [34] suggested that China should try to gradually participate in the secondary CDM market, improve product pricing and control risk. Zhang et al. [35] provided that corporate credit should be reasonably measured and effectively supervised and the mechanisms for carbon trading should be established. Liu [36] studied the carbon accounting standards and the right of forest carbon sinks, argue that the market transaction procedures should be regulated, thus to reduce transaction costs.

\subsection{Policy Support}

Lin [40] considered that the path of low-carbon should be the development of low carbon cities, with the characteristics of low emissions, high energy efficiency, high output, which can be achieved with the joint efforts of the policy incentives of Government and the finance support of financial industry to drive technology innovation. Zhuang [39] argued that the potential ways to achieve low carbon development without affecting the economic development goals in the future might include adjusting the structure of energy and the industry, improving energy efficiency, curb wasteful, develop the potential carbon sink and seek the international economic and technical cooperation. Ren [41] provided that it is urgent to develop low-carbon economy through the establishing of the low carbon economic strategy and legal security system, strengthening the innovation of low-carbon technology, developing low-carbon industries, encouraging enterprises engage in low-carbon production and operation and so on. Under the challenges of economic restructuring, Fan [42] argued that it is need to support low carbon economy for China through national strategy, optimizing energy structure, the transformation of traditional high-carbon industry, policy incentives and so on.

\subsection{Brief Review}

Although some explorations have been made, it has not yet formed a complete, systematic and scientific theory for the financing system of low-carbon development, which can not provide effective policy support or lack of support for the development of low-carbon economy in China, mainly due to that the low carbon economy is still in the early development stages, and the relevant policies, rules and markets has not yet been formed. So it is vital to carry on an in-depth research on financing system for low-carbon development and the corresponding supporting measures, policies and long-effective mechanism.

\section{Foreign Experience}

Low-carbon development policy support. To promote low carbon economy development, the developed countries have been at the forefront: The United States has taken various measures, including legislation, such as the U.S. Senate proposed a "Bill of low-carbon economy" in July 2007; “The Clean Energy Security Act” has been passed in the House of Representatives in U.S. in June, 2009. The security policy mechanism secures the operation of low-carbon economy, such as carbon emissions trading scheme was launched in 2005 in EU. The launch of "the EU Green Paper on Energy Policy" is to increase the investment in energy efficiency, clean energy and the renewable energy research and so on. In March, 2009, the EU announced that the 105 billion euros will have been invested by 2013 to support the "green economy", promote employment and economic growth, to keep the EU a world leader in low carbon industries. It also proposed to increase 50 billion euros earmarked for the development of low carbon technologies in the next decade in October, 2009.

Indirect investment and financing. "Equator Principles" has gradually become an international industry standards and practice in project financing. Foreign commercial banks actively participate in environmental financial innovation, the carbon trading and providing intermediary services for families and SMEs. Such as Dutch bank providing rate discount of $1 \%$ for housing mortgage loan which comply with government environmental standards, U.S. banks providing unsecured loans to small transport companies when they buy fuel-efficient equipment; Barclays Bank launching green credit card and promising that the holders can have a more favorable in the purchase of friendly environmental products; Deutsche Bank introduced energy-saving mortgage loans to customers for the upgrading works of home energy conservation and renewable energy installations. The international communities have set up some self-regulatory organization, which is to promote green finance and supervise the financial institutions engaging in sustainable finance, whose members are from the bank, insurance and securities companies and other financial institutions in the world. The United Nations Environment Programme Department of Finance Initiative sector (UNEP FI) is the most influential one among them.

Low-carbon capital markets. Developed countries use their own sound GEM stock market to promote low- 
carbon economy, such as the London Stock Exchange, there is more than 60 companies listed on GEM, which committed to new technologies of the carbon emissions reduction. Low carbon industries have become a new investment field for international institutional investors and the venture capital. Carbon trading index has become an important index of market indicators, the world's major carbon trading market issued eight influential Lowcarbon index, which influencing the pricing of carbon emissions on the international market. On the basis of these indices, some financial institutions established the ETF funds, such as Easy ETF carbon fund.

Carbon emissions trading market. Global carbon trading market has grown rapidly since the "Kyoto Protocol" formally came into effect in 2005, with total market value of 144 billion U.S. dollars in 2009, and the quota based is 122.8 billion U.S. dollars, the project based is 3.37 billion U.S. dollars [37]. The relevant derivatives transactions also are developed carbon trading market. EUA transactions reached US\$118.5 billion in 2009, making the EU ETS the largest existing carbon market. Over 6.3 billion tCO2e changed hands in 2009 through spot, futures and options contracts. The green Exchange (Green Exchange) is formed by New York Mercantile Exchange (NYMEX) with wide varieties of transactions related to carbon emission rights, renewable energy, environmental futures, options and swaps contracts. Carbon futures also has been launched in Australian Climate Exchange (ACX) and the Australian Stock Exchange (ASX) in early 2009.

\section{The Status and the Limitation of Low-Carbon Investment and Financing in China}

\subsection{The Development Status}

Domestic commercial banks take active measures in the carbon finance business. It has adjusted credit structure to support energy conservation and emission reduction projects by increasing credit for energy conservation and other environmental areas and decreasing the credit quota for high-pollution and high energy consumption industries. For example, 223 energy saving projects was supported by the Industrial Bank at the end of 2009, and the cumulative energy saving loans was issued 16.6 billion yuan. On the other hand, it develops carbon finance business and utilizes a variety of financial tools to support low-carbon economy. The financial products about emissions trading were first launched by the Bank of China and the Shenzhen Development Bank in December, 2009. The Industrial Bank, as the first Equator Principles bank in China, successfully provide project financing for the expansion of Fujian Huadian Power. There is three banks signed the global UNEP FI statement which has been agreed by 200 financial institutions in the world, namely, the Industrial Bank, Shanghai Bank and China Merchants Bank.

China remained the largest Clean Development Mechanism (CDM) seller in carbon emissions market. There is 2,685 CDM projects approved by the Chinese government by the end of September in 2010, which are expected to reduce nearly 500 million tons of carbon dioxide equivalent emission, and 953 projects of which successfully registrated in the United Nations CDM Executive Board and the estimated annual emissions of greenhouse gases achieve to about 2.3 tons of carbon dioxide equivalent. There is no mandatory emission reduction quota for companies, so a voluntary emission reduction will remain the main trade mode in a short term in China. However, the quota trading pilot will be the trend for China. The "Panda standards" issued by the Beijing Environment Exchange in January 2010 will promote the real carbon trading market development in the future. And the Southern low-carbon index, first domestic low-carbon index IPO in the Shenzhen Stock Exchange on September 20, 2010, will lead the domestic green investment. The data from Zero2IPO Research Center shows that the low-carbon industries attract more and more venture capital since 2006. In addition, the GEM in Shenzhen Stock Exchange will also lower the IPO threshold for the industry of new energy and emission reduction. About 200 billion RMB has been invested in the area of energy saving by central government during the period of "Eleventh Five-Year", which driving nearly 2 trillion of social investment.

\subsection{The Current Limitation}

While some explorations have been made in low-carbon finance business by financial institutions, the low-carbon financial system is still in its early stages and the speed of development is very slow. The main current limitation may be as follows.

There is neither a mature Carbon financial institution and product system nor a complete framework for carbon finance system. The basic credit facilities remain the main financial products for low carbon industry, and the product of the forward and futures has not innovated. The main reason may due to that the new energy industry is still in the initial stage of development and there is uncertain input-output ratio which brings great challenges to the risk management for financial institutions. And there is absent of experience for low-carbon finance business, especially in trading rules, risk management and the professional talents.

Carbon market system is imperfect. CDM remain the largest share in carbon market in China which is project- 
based. However there are many risk factors involved in the CDM project for the relatively long development cycle, huge transaction costs, different countries involved, and lack of professional service in domestic carbon market which can offer technical service for financial institutions in analyzing, evaluating, avoiding project risk. There is not yet a unified carbon emission trading market and intermediary service system. The pricing mechanisms for carbon trading urgently need to be set up, as well as the standards of carbon emissions trading. It is a fact that there is no share in quota-based carbon trading for China which accounting for more than $85 \%$ share in the total market capitalization with 122.8 billion U.S. dollars. According to the forecast from New Energy Finance in UK in 2009, the global carbon trading market will become the world's largest market in 2020 with 3.5 trillion U.S. dollars transaction, which is expected to exceed the oil market, and the carbon credits will be the world's largest commodity. Therefore, the absent of domestic carbon trading market would severely limit the further development of carbon finance business.

The low-carbon capital markets should be further improved to allocate the resources through market mechanisms. At present, there are less than 10 companies with the concept of low carbon listed on Shenzhen Stock Exchange and Shanghai Stock Exchange, with 323.36 billion yuan of total market capitalization and $2.76 \%$ of total market value only. Recently the South low-carbon index just listed, it is should be followed by the construction of low-carbon index system in China and the further design of the carbon financial instruments, such as low-carbon ETF, low-carbon index funds, carbon futures, carbon options and more. Moreover, it is still blank for the funds, venture capital and the corporate bonds issued by energy conservation enterprises in China.

Lack of incentive mechanism. Price mechanism can not play a full role in the low-carbon market for economic externalities, and "market failure" appears. The interest conflicts between enterprise and their own social will result in the increase of credit risks in financing institutions when lack of appropriate risk compensation, guarantees and tax deduction. The main reason is that the financial institutions are unable to share the social costs under the current financial regulatory system. The lowcarbon economy is facing more and more severe financing environment because the banks stress the safety, profitability and liquidity of the credit loans, and the stock market require the corporate keep high profits.

Inadequate policy support. The development of Lowcarbon economy is still in the early stage in China, relevant policies, rules have not yet been formed, such as corresponding tax system and low carbon support policy, which is the dependent environment for the diversified investment structure.

\section{The Countermeasures}

It is require that a perfect carbon finance system should be built, embracing a national policy framework consist of corresponding tax deduction system and credit derived financing support services system, a financial institutions system supported by regulatory authorities and public finance, a series of financial instruments including bank loans, direct investment and financing, carbon credits trading, carbon options and futures, and so on.

\subsection{Establishment of a National Low Carbon Policy Framework}

First, it is vital to perfect the low carbon laws and regulations system with increasing the relevant provisions to mitigate the climate change, which will drive the all levels of government, business and the public work together to promote low-carbon transition. Secondly, the next step may take measures to support the transformation of the energy strategic system. It is the global energy strategy characteristic of saving, efficient, cleans, diverse, secure for modern energy system. So development new energy technologies will become the new strategy for most of the governments in the world. It will require the new scheme for property rights exchange and the resources distribution to urge the development of energy saving industry and new energy industry, such as wind energy, nuclear power, solar energy, and so on, as well as the development technology for energy saving, carbon capture and storage. Third, a low carbon public finance system should to be established, which will play a great role on solving the externalities of environmental issues, for the resource tax will encourage the rational development of resources, promote the use of renewable resources, and the favorable policy on tax will guide the low-carbon production and consumption, push the commercial banks provide financial support for the low carbon field, and also can accumulate low carbon develop funds, as well as the utilization of the government prices Regulation, procurement policy and information dissemination to drive the low carbon production and consumption. Fourth, the green accounting and audit system should be introduced that will help the establishment of monitoring mechanisms and evaluation system for green behavior. Through the above measures taken, a long-term mechanism for low carbon development will gradually formed in future.

\subsection{The Sound Bank-Based Financial Institutions and Products System}

Sound low carbon credit system. As the core of China's financial system, commercial bank should be a major 
force for low-carbon economy development, so it should play its due position to build a sound low carbon credit system under the "Equator Principles". First, the green credit system should be established that focus on the financial mode meet the demand of low carbon industry with one hand support for low-carbon financial business and the other hand restrain the high carbon loan issue. Second, in addition to the basic credit facilities, the innovative instruments should also be developed, including financial derivatives, joint equity, bonds, etc, which broaden the financial channel for SMEs. Third, it should pay attention to improve the carbon credit risk management system because carbon finance business often face a varieties of risks with the long process cycle, intensive technology, policy risk, inadequate business credit issues. It is vital to take measures to control the bank's credit risk, including introducing the environmental risk management, risk sharing mechanism, technical certification for projects, seeking cooperation with the guarantee fund or a professional security agencies, and so on.

Perfect Financial institutions. First of all, it is reasonable to promote the low-carbon credit business cooperation among commercial banks, which utilize the size advantage and strengthen capability to solving the high-risk at early stage of carbon finance business. Secondly, it requires a diversified investment patterns, with the joint efforts of the local government financing platform, insurance companies, venture capital, institutional investors and other parties, to provide low carbon financial services, such as guarantees, risk compensation, insurance, etc. Third, it is an integral part of low carbon financial system that the intermediary system providing professional technical advisory which improve the development of low carbon market and help banks and other financial institutions to analyze, evaluate, avoid risks come from the development and transaction of low carbon business.

It is significant that the measures made to perfect the low carbon financial institutions and products system which will broaden the financing channels for low carbon enterprises, improve the development of low-carbon economy, as well as their own development.

\subsection{A Sound Low-Carbon Financing Market System}

\subsubsection{The Establishment of a National Carbon Trading Market}

The credit subject. It is the first job for the low carbon trading system to define the carbon emission rights for the economic entities. In theory, the reduction is the responsibility for every entity, but in fact, it is unable to force every entity to participate trade in the carbon market. The entities involved in EU emissions market is generally limited to the energy-intensive industries, such as power generation, heating industry, oil refining, coking, iron and steel, cement, glass, lime, brick, ceramics, pulp and paper and so on.

Rational allocation of credit. Reasonable distribution of credit is the basis of carbon trading mechanisms. As the property rights are the base of the market, the emission market is unable to play its due role in absent of the clear definition of emission rights. If the allocation of emissions are too loose, it will lead to the proliferation of carbon credits and the decrease of prices of the emission rights, thus will lose the incentive effect for emission deduction. Therefore, the rational allocation of emission rights directly affects the function of trading system. It is the functions of government to define implement and monitor the operation of greenhouse gas emissions, and the prompt measures should be made by the Chinese government to set up the carbon emission rights system for initial allocation.

The mechanisms of check and punishment. Carbon emissions rights is a scarce source, whose price shows the value of carbon credit. If the emission behavior without corresponding monitoring, the entity will have the urge to use the emissions rights excessively, which will harm the foundation of emission rights market. Therefore, the emission behavior should be under severely monitoring mechanism which can successfully guarantee the due emission behavior with survey, reporting and verification of real carbon emissions. The corresponding penalty system should take effect when the excessive emission actually happened, which make sure to prevent the prevalence of opportunism and protect the due interest of low carbon entities. In addition to pay the fine, the entities with excessive emission can not be exempted from the mandatory liability provisions, whose allocation must be deducted from that of the next year. It is approved that this kind of punishment mechanisms has played an important role for the successfully operation of the EU emissions trading scheme.

Establishment a carbon emissions exchange system. First, the basis of carbon emissions data system should be collected. To collect the accurate, reliable, timely and transparent corporate carbon emissions data, it can first build an accounting system for carbon emissions in the energy-intensive industries, then gradually promoted to other sectors. Second, a unified national carbon exchange should be founded with the integration of existing resources and information, as well as a unified national automated quotation system, which will become a integral part of the financial market, like stock exchange, futures exchange and financial futures exchanges. The rules and standards of carbon trading system should be further explored, and the construction of the pricing me- 
chanism for carbon trading should be promoted, which will help the development of the quota-based trading system. Third, it is the multi-level investment system should be established to meet the demand of carbon market development, which will attract more financial institutions to participate in carbon trading markets, and upgrade the low carbon industry. Fourth, it deserve to pay attention to changing the low-end position in the global CDM market and increase the income of the CDM owner, thus will protect the strategic interests of the China. Then, the measures should be made to cultivate a professional technical advisory system to help financial institutions to analyze, evaluate and manage risks of CDM projects, with the reference to the theory and practice from foreign intermediary market. And it is very important to strengthen the cooperation between the domestic financial institutions and foreign agencies, to encourage private capital investment, help the intermediary service system be formed. Fifth, it is vital to make frontier research on the "carbon currency" and settlement currency, to take actively in international monetary system reform. It will minimize the settlement risks when the RMB as one of the payment currency in carbon trading, which will in fact promote the process of internationalization of RMB and be a key step in pricing power in the new energy field for China.

\subsubsection{Improvement of Low-Carbon Capital Markets}

Development of multi-level investment. First of all, the local governments should establish low-carbon funds to guide and promote social capital invest in low-carbon industries, including $\mathrm{PE}, \mathrm{VC}$, and some trust funds, etc, and long-term carbon bonds with the central government credit guarantees should be issued, which will help the establishment of a reasonable cost share mechanisms for the intergenerational financing. Second, the government can take some special measures to encourage both large scale enterprises and private and personal capital to participate in the development of the low-carbon economy with the utilizing of special policies, tax leverage, economic instruments, government procurement policy, and so on. Third, A special development fund for low-carbon economy should be set up by China Development Bank (CDB), which will play full role of the advantage of policy bank to provide the financial support for national and cross-regional low-carbon projects.

Promotion the founding of low-carbon capital market. First, Reference to the development experience of SME, the regulatory should support the IPO, corporate bonds and medium term notes for low-carbon companies, and guide the social capital in favor of low carbon field. Second, through the innovation of financial models including the BOT project finance and asset securitization, it can improve the environmental quality, transfer environmental risk, and meet the market demand. It also can get the financial support from international financial institutions, intergovernmental organizations and international capital markets for the development of low-carbon economy in China. Third, it is vital to improve the construction of China's low-carbon index system, which is the base of innovation of financial derivatives, such as carbon futures, options and the other, and will lead the green investment.

\subsection{The Improvement of the Low-Carbon Financial Eco-System}

As good incentive mechanisms, the low-carbon financial eco-system should be an integral part of low-carbon financing system. The follow measures should be taken to perfect low-carbon financial eco-system: First, a sound system of policies and regulations should be established, the property rights and responsibilities of carbon emission should be recognized which is the preconditions for the domestic carbon trading market system, the environmental responsibility for financial institutions should be strengthened which will promote the improvement on corporate governance of financial institutions and the corresponding innovation on environmental financial instruments. Second, the financial discount system for low-carbon industries should be established. With the combination of financial subsidies and bank credit, it will mobilize the enthusiasm of the Bank and the investors at all levels, expand investment scale, adjust the investment structure, and increase investment efficiency. Third, it is vital to promote low-carbon financial regulatory system. In the process of transformation of economic development, the financial regulators should update the regulatory philosophy and improve the regulatory capacity to actively respond to new financial risks from home and abroad, minimize the settlement risks. It should take measures to monitor the implementation of the government discount policy and evaluate its results, to increase the efficiency of public finance and ensure that is consistent with macro-control goals. Fourth, it is urgent to improve the low-carbon personnel training system. The low-carbon development of financial markets is bound to increase the demand for professionals that must have a solid theory, knowledge and risk management skills not only in the field of finance but also in low-carbon industry. In the long run, it should take great efforts to make long-term plan for the development of high-quality low-carbon financial personnel meet the urgent need for the development of low carbon finance business.

In short, the building of low-carbon financing system is a systematic project, which requires the improvement of low carbon financial institutions and products system, 
the low carbon financial market system, the low carbon financial eco-system, and the low carbon development related institutions, mechanisms, rules, which will encourage individuals, businesses and financial institutions to invest in the field of new energy and emission deduction, thus promote the innovation of low-carbon technology and the development of low-carbon economy.

\section{REFERENCES}

[1] V. Bencivenga and B. Smith, "Financial Intermediation and Endogenous Growth,” Journal of Review of Economics Studies, Vol. 58, No. 2, 1991, pp. 195-209.

[2] R. G. King and R. Levine, "Finance and Growth: Schumpeter Might Be Right," The Quarterly Journal of Economics, Vol. 108, No. 3, 1993, pp. 717-737.

[3] P. Krugman and J. A. Venables, "Globalization and the Inequality of Nations," The Quarterly Journal of Economics, Vol. 110, No. 4, 1995, pp. 857-880.

[4] R. C. Merton, "A Functional Perspective of Financial Intermediation,” Financial Management, Vol. 24, No. 2, 1995, pp. 23-41.

[5] R. Levine, "Financial Development and Eeonomic Growth: Views and Agenda,” Journal of Economic Literature, Vol. 35, No. 2, 1997, pp. 688-726.

[6] P. M. Romer, "Increasing Returns and Long-Run Growth,” Journal of Political Economy, Vol. 94, No. 5, 1986, pp. 1002-1037.

[7] L. Robert, "On the Mechanics of Economic Development," Journal of Monetary Economies, Vol. 22, No. 1, 1988, pp. 3-42.

[8] P. M. Romer, "Endogenous Technological Change," Journal of Political Economy, Vol. 98, No. 5, 1990, pp. 71-102.

[9] Y. J. Tang and D. F. Li, "Environmental Capital, Negative Externality and Carbon Finance Innovation," China Industrial Economics, No. 6, 2010, pp. 5-14.

[10] Y. Deng, "The Low Carbon Economy and the Building of Environmental Finance in China," On Economic Problems, No. 9, 2010, pp. 38-41.

[11] L. Q. Chen, "Research on Financial Support to Develop Low-Carbon Economy," Journal of Financial Development Research, No. 7, 2010, pp.12-18.

[12] J. T. Ganzi and J. Tanner, "Global Survey on Environmental Policies and Practices of the Financial Services Industry: The Private Sector," National Wildlife Federation, Environment and Finance Enterprise, Washington, DC, 1997. http://www.nwf.org

[13] L. Montes, "Financing Sustainable Development in Mexico through Alternative Banks or 'Green Banks,"” The Journal of Structured Finance Spring, Vol. 4, No. 1, 1998, pp. 67-71.

[14] A. B. Coulson, "Vivienne Monks. Corporate Environmental Performance Considerations within Bank Lending Decisions," Corporate Social Responsibility and Envi- ronmental Management, Vol. 6, No. 1, 1999, pp. 1-10.

[15] M. Jeucken, "Sustainable Finance and Banking: The Financial Sector and the Future of the Planet," Earthscan Publications Ltd, 2001, pp. 118-146.

[16] S. Labatt and R. R. White, "Environmental Finance: A Guide to Environmental Risk Assessment and Financial Products,” John Wiley \& Sons, Inc, New York, 2002.

[17] K. Dahlstrom, J. Skea and W. Stahel, "Innovation, Insurability and Sustainable Development: Sharing Risk Management between Insurers and the State," The Geneva Papers, Vol. 28, No. 3, 2003, pp. 394-412.

[18] CEO Briefing, "Renewable Energy, Geneva: Climate Change Working Group," United Nations Environment Programme Finance Initiative, New York, 2004.

[19] "Financial Risk Management Instruments for Renewable Energy Projects,” UNEP Sustainable Energy Finance Initiative (SEFI), Paris, 2004.

[20] A. Dlugolecki, "Climate Change and the Insurance Sector,” The Geneva Papers, Vol. 33, 2008, pp. 71-90.

[21] H. Wei and Y. H. Li, "Create a Learning Commercial Banks to Enhance Market Competitiveness,” Commercial Research, Vol. 15, 2004, pp. 42-46.

[22] D. He and X. L. Zhang, “The Study on Implement Green Credit of Commercial Banks in China," Shanghai Finance, Vol. 12, 2007, pp. 4-9.

[23] L. H. DING, "A Study on Finance Supporting the Development of Circular Economy," Science Technology and Industry, Vol. 8, 2007, pp. 87-89.

[24] Y. Chen, "Carbon Finance:Opportunities and Challenges for China s Commercial Banks," Finance \& Economics, Vol. 11, 2009, pp. 8-15.

[25] S. Borenstein, "On the Efficiency of Competitive Markets for Operating Licenses,” Quarterly Journal of Economics, Vol. 103, No. 2, 1998, pp. 357-385.

[26] P, Cramton and S. Kerr, "Tradable Carbon Permit Auctions - How and Why to Auction not Grandfather," Energy Policy, Vol. 30, No. 4, 2002, pp. 333-345.

[27] E. S. Sartzetakis, "On the Efficiency of Competitive Markets for Emission Permits," Environmental and Resource Economics, Vol. 27, No. 10, 2004, pp. 1-19.

[28] S. D. Li and S. P. Yin, "The Study on the Initial Allocation and the Pricing of Emissions Trading," Science of Science and Management of S. \& T., Vol. 23, No. 1, 2002, pp. 69-71.

[29] D. H. Chen, S. D. Li and F. Jiang, "Oligopoly and Initiate Allocation of Emission Right,” Systems Engineering, Vol. 22, No. 10, 2004, pp. 51-53.

[30] R. N. Stavins, "Transactions Costs and Tradable Permits," Journal of Environmental Economics and Management, Vol. 29, No. 2, 1995, pp. 133-148.

[31] L. Gandgadharan, "Transaction Costs in Pollution Markets: an Empirical Study,” Land Economics, Vol. 76, No. 4, 2000, pp. 601-614.

[32] W. F. Ren, "The Low Carbon Economy and the Environmental Financial Innovation," Shanghai Economic 
Review, No. 3, 2008, pp. 38-42.

[33] L. Z. Wang and Y. Z. Song, "On the Present Situation of Carbon Trade in China and its Financial Innovation," Modern Finance and Economics-Journal of Tianjin University of Finance and Economics, Vol. 29, No. 6, 2009, pp. 30-34.

[34] Z. W. Wang and Z. T. Yuan, "The Product Innovation in Carbon Finance Market,” China Finance, 2009, No. 24, pp. 51-52.

[35] M. Q. Zhang and G.F. Lu, "The Study on Mechanism of the Carbon Trading Market,” Environmental Protection, Vol. 412, No. 1B, 2009, pp. 78-81.

[36] N. Liu, "A Study on the Prospects of China's Carbon Trading Market,” Inner Mongolia Science Technology \& Economy, Vol. 8, No. 4, 2009, pp. 12-14.

[37] State and Trends of the Carbon Market, World Bank,
2010, p. 12.

[38] Annual Sustainability Report, Industrial Bank, 2009, p. 42.

[39] G. Y. Zhuang, "The Analysis on Ways and Potential of Low Carbon Economic Development in China," Studies in International Technology and Economy, Vol. 8, No. 3, 2005, pp. 8-12.

[40] B. Q. Lin, "What Issues Need to be Resolved in the Development of Low Carbon Economy," China Small \& Medium Enterprises, No. 9, 2009, pp. 25-26.

[41] L. Ren, "The Foreign Policy of Developing Low Carbon Economy,” Development Research, No. 2, 2009, pp. 2327.

[42] Y. T. Fan and M. Z. Li, "Low-Carbon Economic and Chinese Transformation on the Development Mode," Shanghai Journal of Economics, No. 2, 2010, pp. 30-35. 